\title{
STUDIES OF MEIOTIC BEHAVIORS IN SOME TAXA OF THE NEPALESE PAPILIONACEAE
}

\author{
L. Manandhar and S.R. Sakya
}

\section{ABSTRACT}

This paper reports studies of meiotic behaviors of seventeen species, sub-species and varieties in seven genera of the Nepalese Papilionaceae and new chromosome numbers for three species (Crotalaria cytisoides Roxb. ex DC ( $n=8)$, Parochetus communis Buch-Ham. ex D. Don $(n=8)$ and Piptanthus nepalensis (Hook.) D. Don. $(n=9,18)$ are new number reports. Meiotic behaviors are often normal in all the species). However, a few aberrations like univalents, chromosome bridges, laggards, precocious chromosomes and/ or cytomixis have been observed in most of the taxa. Pollen fertility is high (more than 80\%) indicating that the abnormalities had not reached mature stages.

Key words: haploid chromosome count, metaphase I, meiosis

\section{INTRODUCTION}

Papilionaceae consisting of 455 genera and 12,615 species (Brummit 1992, Judd et al. 1999) are cosmopoliton in distribution. About 80 genera and c. 290 species are reported from different regions of Nepal (Rajbhandari 2002-2003, Press et. al. 2000, Hara and Williams 1979, Ohashi 1975). Fourteen species of them are endemic to Nepal (Shrestha and Joshi 1996). These taxa are of great economic values because their roots exhibit peculiar tubercles containing bacterial organisms (Rhizobium species), are able to take up a lot of atmospheric nitrogen to enrich the soil. The plants have been used as fodder in the hilly regions of Nepal. They are good soil binders. They add beauty to the forests during their blooming periods. Taxa included in the present investigation are significant also for their uses in traditional medicines like tonic and to cure various diseases like coughs and convulsions etc. Some of them are used as forage, fibre and ornamental plants (Kirtikar and Basu 1935, Chopra et al. 1956, Tanaka 1976, Nair and Mohanan 1998).

\section{MATERIALS AND METHODS}

Plants were collected from different regions of the country and living plants with collection numbers (Coll. N.) were established in home garden for investigation. Flower buds from the plants of the pots were fixed in 1:3 acetic alcohol for $24 \mathrm{c}$. Proper anthers were chosen and squashed in $2 \%$ aceto-carmine. Cytological studies of the pollen mother cells of the taxa were done with the help of compound microscope. The meiotic behaviors were recorded and photographs of appropriate stages are used as illustrations. Pollen fertility was estimated by staining pollen grains in the Muntzing solution i.e. 1:1 acetocarmine and glycerine (Muntzing 1941). All the photomicrographs were taken under the uniform magnification of 1000x oil immersion. 
Locality: Kirtipur road side (central Nepal) $1300 \mathrm{msl}$

Meiotic behaviour was mostly regular at diakinesis, metaphase I, anaphase I and telophase I. Eight bivalents at diakinesis were (Figure 1) rings and rods. Figure 2 shows dimorphic pollens. Pollen stainability was found to be $98.8 \%$.

The chromosome number $n=8$ counted during the investigation for Alysicarpus rugosus tallies with the reports $2 \mathrm{n}=16$ by Rao (1954), John et al. (1985), Peng and Chaw (1986), Kumari and Bir (1990), Sinha and Chandra (1991) and $n=8$ by Jahan et al. (1994). This species seems to be a diploid with the basic number $x=8$.

\section{Alysicarpus vaginalis (L.) DC. (Coll. N. 138)}

Locality: Biratnagar (East Nepal) $72 \mathrm{msl}$

The haploid number in this taxa is $n=16$. Meiotic divisions were observed regular at various stages. Figure 3 is anaphase II with precocious movement of some chromosomes. Nonorganised groupings and scattered chromosomes were observed at telophase II occasionally. Cytomixis has been recorded at different stages. Pollen stainability was found to be $99.7 \%$. A. vaginalis was found to be with the haploid number $n=16$ during the present investigation. This haploid number $n=16$ is a new report for the species because it differs from the previous reports 2n=16 by Rao (1954), Frahm-Leliveld (1957), Bhatt (1974), Sanjappa and Bhatt (1976, 1978), John et al. (1985), Yeh et al. (1986), Sinha and Chandra (1991), 2n=20 by Gadella and Kliphius (1964), 2n=14 by Kapali and Patil (1987), $n=8$ by Bir and Sidhu (1966, 1967), Mitra and Datta (1967), Sareen and Singh (1976), Sanjappa and Bhatt (1978). The present species from Nepal seems to be a tetraploid one.

\section{Astragallus chlorostachys Lindl. (Coll. N.133)}

Locality: Tadapani, Banthanti (West Nepal) 2650 msl growing on the moist place on the hill near road side

Chromosomes at metaphase I revealed 8 unequel sized bivalents. Figure 4 has evidenced sticky chromosomes at metaphase I. A few abnormalities like formation of univalents and multivalents, chromatin stickiness and agglutination, multipolar movements of chromosomes and cytomictic cells were developed in some cells. Pollen stainability was found to be $99.5 \%$.

\section{Astragalis stipulatus var. phulchokiensis H. Ohashi (Coll. N. 134)}

Locality: Phulchoki (C. Nepal) 2200 msl

At diakinesis chromosomes revealed 12 unequal sized bivalents (Figure 5). The irregularities during the divisions contained multivalents, stickiness, agglutination, non-synchronous movements. Pollen stainability was found to be $99.1 \%$.

The haploid number of the genus Astragalus $6,7,8,9,11,13,15,2023$ or polyploidy forms of these numbers (Chinnappa and Chmielewski 1987, Spellenberg and Rodrigues 1992, Pavlova 1995, Badr et al. 1996, Manandhar and Sakya 2004). The numbers found may be due to the development of hypoploids or hyperploids with basic number $x=8$ or of secondary origin. The haploid number $n=8$ of $A$. chlorostachys confirms the previous reports $2 n=16$ (Ledingham 1960 , Ledingham and Rever 1963, Manandhar and Sakya 2004) and n= 8 (Asharf and Gohil 1989, 
Kumari et al. 1989, Manandhar and Sakya 2004). This species is a diploid one with basic number $\mathrm{x}=8$. The number $\mathrm{n}=12$ of $A$. stipulatus var. phulchokiensis is different from previously reported number $2 n=64$ of $A$. stipulatus (Ledingham 1960). The number $n=12$ and $2 n=24$ is reported in this variety by Manandhar and Sakya (2004). The presently collected variety phulchokiensis of $A$. stipulatus is with the basic number 6 . This suggests that both structural alteration as well as numerical mutations might have been occurred during the course of evolution in this genus.

\section{Crotalaria cytisoides Roxb. ex DC. (Coll. N. 122)}

Locality: Nagarjun hill (Central Nepal) 1520 msl

Meiosis was regular. In metaphase I, bivalents and tetravalents with 1 to 3 B chromosomes was observed (Figure 6). Diads and pentads were also recorded. Pollen stainability was found to be $99.6 \%$.

\section{Crotalaria pallida Aiton (Coll. N. 147)}

Locality: Central Department of Botany garden, Kirtipur (Central Nepal) 1310 msl

Meiosis evidenced 8 unequal sized bivalents with one or two Bs. Bivalents at diakinesis were rings and rods. Figure 7 is metaphase II with 8 chromosomes at each pole. Some irregularities like stickiness, spindle fibres and chromatin bridges were prominent at different stages. Pollen stainability was found to be $99.8 \%$.

\section{Crotalaria sessiliflora L. (Coll. N. 124)}

Locality:Bajrajogini area (C. Nepal) 1520 msl

Eight bivalents, in two chains with rods and one separate ring chromosome, are observed in Figure 8. Meiosis is fairly normal at different stages. Pollen stainability was found to be $99.8 \%$.

The haploid number $n=8$ reported here in Crotalaria cytisoides tallies with the previous reports $2 n=16$ (Manandhar and Sakya 2003a, 2003b). The number $n=8$ reported presently in C. pallida confirms the previous reports $n=8$ by Bajracharya and Joshi (1980), Sarkar et al. (1982), Bairiganjan and Patnaik (1989) and $2 \mathrm{n}=16$ by Bajracharya and Joshi (1979), Raina and Verma (1979), Kumari and Bir (1990), Oliviera and Aguiar-Percin (1989), Mangotra and Koul (1991a). The number $n=8$ C. sessilflora confirms $2 n=16$ by Kumari and Bir (1990), Gu and Sun (1996). It reveals that Crotalaria is a monobasic genus with $x=8$, structural changes might have played important role among the species of this genus during the course of evolution. However Mangottra and Koul (1991b) have encountered polyploidy in several species of the genus Crotalaria indicating numerical change in chromosomes also have some role in evolution.

\section{Desmodium concinnum var. concinnum DC. (Coll. N. 109)}

Locality: Palung (Central Nepal) $2150 \mathrm{msl}$

Eleven bivalents were observed at diakinesis and metaphase I (Figure 9). Sometimes tetravalents were also observed. Chromosomes were towards peripheral regions. Second meiotic divisions were almost normal with some degree of stickiness. Figure 10 shows cytomixis of two cells at metaphase I. Normal decussate tetrads were observed. Pollen stainability was found to be $97.0 \%$. 
Desmodium elegans DC. ssp. elegans var. elegans (Coll. N. 111)

Locality: Shivapuri hill (C. Nepal) 2000 msl

It showed 11 bivalents at diakinesis as rings and rods (Figure 11). Some mulivalents were frequently observed at metaphase I. The second meiotic divisions evidenced certain irregularities like exclusion of one or more chromosomes at metaphase II. Stickiness and chromatin bridges had been observed during anaphase II (Figure 12). Multicellular polyads were also seen. Pollen stainability was found to be $98.9 \%$.

Desmodium laxiflorum DC. (Coll. N.103)

Locality: Nagarjun forest (Central Nepal) 1500 msl

Eleven bivalents were observed at diakinesis (Figure13). Rings and rods with few tetravalents were seen frequently. Exclusion and shifting of a group of chromosomes towards periphery had been observed. Sticky chromosomes, non-synchronous divisions, agglutination had been noticed. Pentads and polyads with 8 to 12 celled structures were also recorded. Pollen stainability was found to be $98.7 \%$.

\section{Desmodium multiflorum DC. (Coll. N.110)}

Locality: Nagarjun forest (Central Nepal) 1510 msl

In metaphase I, chromosomes with both 11 and 22 bivalents were observed in different individuals of this species. Figure 14 is metaphase I of tetraploid species with 22 bivalents. Tetraploid plants were robust with with larger vegetative and floral parts compared to those of diploid ones. Both I and II meiotic divisions were normal with occasional occurrence of movement of chromosome towards periphery and cytomixis. Pollen stainability was found to be $95.5 \%$.

Desmodium podocarpum ssp oxyphyllum DC. var. oxyphyllum (Coll. N. 114)

Locality: Phulchoki (C. Nepal) 2200 msl.

Eleven bivalents had been recorded at diakinesis (Figure 15) in rings and rods. Meiosis in different stages were recorded fairly normal. Pollen stainability was found to be $99.5 \%$

Desmodium podocarpum DC. ssp. podocarpum (Coll. N. 108)

Locality: Namobuddha (Central Nepal) 1780 msl.

Ring and rod bivalents at diakinesis are common. Figure 16 shows sticky chromosomes at metaphase II. In most of the miocytes divisions were normal. Pollen stainability was found to be $99.1 \%$.

Desmodium triflorum (L.) DC. (Coll. N. 106)

Locality: Dhulikhel (C. Nepal) 1420 msl.

At diakinesis 11 bivalent had been recorded with one or two bivalents attached to the nucleolus Stickiness of bivalents have evidenced to form rings (Figure 17). Occasional irregularities during the divisions had evidenced multipolar movement of chromosomes at metaphase II. Pollen stainability was found to be $95.8 \%$. 
The chromosome number $n=11$ is confirmed in the present investigation for the genus Desmodium. This report tallies with the previous reports $n=11$ or/and $2 n=22$ by several authors (Ranjit 1978, Sanjappa and Bhatt 1985, Yeh et al. 1986, Bairiganjan and Patnaik 1989, Kumari and Bir 1990, Kumar and Kuriachan 1990, Jahan et al. 1994, Gao and Zou 1995, Manandhar and Sakya 2003a, 2003b). However, $n=22,2 n=44$ have been reported by Manandhar and Sakya (2003a) in D. multiflorum seems to be the tetraploid one.

\section{Parochetus communis Buch.-Ham. ex D. Don (Coll. N. 132)}

Locality: Kharidhunga (C. Nepal) 2400 msl

Haploid chromosome number in this taxa is $n=8$. Ring as well as rod tetravalents and bivalents were recorded at diakinesis (Figure 18). Meiosis was found to be fairly normal. Figure 19 was normal anaphase II. There were evidences of sticky chromosomes occasionally. Pollen stainability was found to be $95.6 \%$.

The present haploid number report $n=8$ in Parochetus communis tallies with the reports $n=8$ by Malakar (1978) and $2 \mathrm{n}=16$ by Berger et al. (1958), Dhakhwa (1979 and Chatterjee et al. (1989). It could be that the taxa investigated here is a diploid one with basic number $x=8$.

\section{Piptanthus nepalensis (Hook.) D. Don. (Coll. N.136)}

Locality: Kalinchok (C. Nepal) $3300 \mathrm{msl}$

Both $n=9$ and $n=18$ were observed in different individuals of this taxa. Meiosis evidenced certain irregularities. Stickiness is noted at diakinesis and metaphase I. Rod bivalents are more common. Non-oriented and lagging chromosomes are observed at different stages. Figure 20 shows diakinesis in a tetraploid cell. Cytomictic cells were also observed (Figure 21). Pollens were dimorphic. Pollen stainability was found to be $80.8 \%$. Haploid numbers $n=9,18$ are new reports for Piptanthus nepalensis.

Piptanthus nepalensis reported with $n=9$ presently confirms the earlier reports $n=8$ by Malakar (1978) and $2 \mathrm{n}=18$ by Berger et al. (1958) and Manandhar and Sakya (2003b). It could be that the taxa, reported in this investigation, is a diploid one.

\section{Smithia ciliata Royle (Coll. N. 136)}

Locality:Panighat, 1700 msl.

Nineteen bivalents, all rod-like, have been observed at metaphase I (Figure 22). Sometimes disjointed bivalents are noted. In most of the cases, meiosis is quite normal. Pollen stainability was found to be $95.2 \%$.

Smithia ciliata with $n=19$ have been reported here that tallies with the previous report $n=9$, $2 n=38$ in this taxa (Tuladhar 1978, Manandhar and Sakya 2009). The haploid number $n=19$ in this species is a new chromosome number addition to the world flora. The chromosome counts $2 n=38$ in S. bigemina and S. conferta by Kumari and Bir (1990), Kumar and Kuriachan (1990) and haploid number $n=19$ in S. sensitiva by Mitra and Datta (1967) and in S. racemosa by Kumar and Kuriachan (1990) suggest that Smithia is a monobasic genus with the basic number $n=19$. It may be due to a genotypically controlled stability of the chromosome number in the genus Smithia. 
The perusal of literature (Darlington and Janaki Amal 1945, Darlington and Wylie 1955, Fedorov 1969, Kumar and Subramanian 1986, Mangotra and Koul 1991a, Chen et al. 1993, Chen et al. 2003) and also the above findings, suggest that the deeply sealed basic number is, $n=8$ in Alysicarpus, Astragalus, Crotalaria and Parochetus, $n=11$ in Desmodium, $n=9$ in Piptanthus and $\mathrm{n}=19$ in Smithia.

\section{ACKNOWLEDGEMENTS}

We wish to acknowledge all those who have supported us during the research work.

\section{REFERENCES}

Ashraf, M. and R.N. Gohil,1989. Studies on the cytology of legumes of Kashmir Himalaya IV. Meiotic behaviour in 21 species of Astragalus. Cytologia, 54:565-571.

Badr, A., M.A. Hamoud and H.A. El-Rabey,1996. Chromosomal studies in Egyptian flora V. Chromosomal relationships in the genus Astragalus $L$. (Fabaceae) and their taxonomic inferences. Cytologia, 61:105-111.

Bairiganjan, G.C. and S.N. Patnaik,1989. Chromosomal evolution in Fabaceae Cytologia, 54: 51-64.

Bajracharya, J. and K.K. Joshi,1979. Karyomorphological studies in six species of Crotalaria L. Jour. of Nat. Hist. Mus., 3(3):75-82.

Bajracharya, J. and K.K. Joshi,1980. Cytological studies in some wild and cultivated species of Crotalaria L. J. Inst. Sc., 3(1):25-30.

Berger, C.A., E.R. Witkus and M.R. Memahon,1958. Cytotaxonomic studies in the Leguminosae. Bull. Torrey Bot. Club., 85:405-414.

Bhatt, R.P.,1974. Studies on flora of north Gujarat III cytology. The Nucleus, 17:33-39.

Bir, S.S. and S. Sidhu,1966. Chromosome number reports VI. Taxon, 15:117-128.

Bir, S.S. and S. Sidhu,1967. Cytological observations on the north Indian members of family Leguminosae. The Nucleus, 10:47-63.

Bir, S.S. and S. Kumari,1973. Chromosome number reports. Taxon, 22:459-464.

Bir, S.S. and S. Kumari,1975. Chromosome number reports XLIX. Taxon, 24: 501-516.

Bir, S.S. and S. Kumari,1977. Evolutionary status of Leguminosae from Panchamarhi, central India. The Nucleus, 20:94-98.

Brummitt, R.K.,1992. Vascular plant families and genera. The board of trustees of the royal botanical gardens, Kew.

Chatterjee, A., S. Ghosh and S.C. Roy,1989. A cytological survey of eastern Himalayan plants. III. Cell and Chromosome Research, 12:22-29.

Chen R.Y., S.H. Lin and W.Q. Song Chen,1993, Chromosome atlas of Chinese principal economic plants. Tomus I: Chromosome atlas of Chinese fruit. International Academic Publishers, Beijing, China. 
Chen R.Y., W.Q. Song and X.L. Li, 2003. Chromosome atlas of major economic plants genome in China. Science Press, Beijing, China.

Chinnappa, C.C. and J.G. Chmielewski,1987. Documented plant chromosome numbers 1987:1. Mecillaneous counts from western north America. Sida, 12:409-417

Chopra, R.N., S.L. Nayar and I.C. Chopra,1956. Glossary of Indian medicinal plants. Council of scientific and Industrial Research, New Delhi, India.

Darlington, C.D. and E.K. Janaki Amal,1945. Chromosome atlas of cultivated plants. George Allen and Unwin Ltd, London, UK.

Darlington, C.D. and A.P. Wylie,1955. Chromosome atlas of flowering plants. George Allen and Unwin Ltd, London, UK.

Dhakhwa, A.R.,1979. Karyological studies on tribe Trifloreae. M Sc Thesis, Tribhuvan University, Nepal.

Fedorov, A.A. (ed),1969. Chromosome numbers of flowering plants. Science Press, V. L. Academy of Science of USSR, Komarov Botanical Institute, Russia.

Frahm-Leliveld, J. A.,1957. Observations cytologique legumineuses tropicales et subtropicales. Rev. Cytol. Et Biol. Veg., 18:273-287.

Gadella, T.W.J. and E. Kliphius,1964. Chromosome numbers of some flowering plants collected in Surinum, Acta Bot. Neerlandica, 13:432-433.

Gao, C. Z. and Q.L. Zou,1995. A report on the karyotypes and chromosome numbers of some taxa of Desmodium (sensu lat.) from Guangxi. Guihaia, 15: 166-171. Available at http//mobot. mobot.org-Missouri Botanical Garden's VAST: w3 Tropicos.

$\mathrm{Gu}, \mathrm{Z}$. and H. Sun,1996. A cytological study of some plants from Quinghi-Xizang plateau. pp. 84-85. International symposium on floristic characteristics and diversity of east Asian plants.

Hara, H. and L.H.J. Williams,1979. An enumeration of flowering plants of Nepal. British Museum, London.

Jahan, B, A.A. Vahidy and S.I. Ali,1994. Chromosome numbers in some taxa of Fabaceae mostly native of Pakisthan. Annals of Missouri Botanical Garden, 81:792-799.

John, C.K., R.J. Thengane and S.H. Tulpule,1985. A post pachytene diffuge stage in Alysicarpus rugosus DC. Curr. Sci., 54:938-939.

Judd, W.S., C. Campbell, S. Kollogg, S. Elizabeth and P.F. Stevens,1999. Plant systematics a phylogenetic approach. Sinauer Associates, Inc. Publishers Sunderland, Massachutts, USA .

Kappali, S.A. and B.C. Patil, 1987. Chromosome number reports 95. Taxon, 36:493.

Kirtikar, K.R. and B.D. Basu, 1935. Indian medicinal plants Vol. I. Lalit Mohan Basu, Allahabad, India.

Kondo, K., R. Tanaka and M. Segawa,1977. Intraspecific variation of karyotypes in some species of Lespideza and Desmodium. Kromosoma, 11-15:123-137. 
Kumar, M.G.V. and P.I. Kuriachan,1990. SOCGI plant chromosome number reports-IX. J. Cytol. Genet., 25:145-147.

Kumari, S. and S.S. Bir,1990. Karyomorphological evolution in Papilionaceae. J. Cytol. Genet., 25:173-219.

Kumar, V. and B. Subramaniam,1986. Chromosome atlas of flowering plants of Indian subcontinent.Vol. I. Bot. Sur. Ind., New Delhi, India.

Kumari, S.M., I.S. Saggoo and J. Kour,1989. SOCGI Plant chromosome number reports VIII. J. Cytol and Genet., 24:179-183.

Ledingham, G.F.,1960. Chromosome numbers of Astragalus and Oxytropis. Canadian J. Genet. and Cytol,. 2(2):119-128.

Ledingham, G.F. and B.M. Rever,1963. Chromosome numbers of some southwest Asian species of Astragalus and Oxytropis (Leguminosae). Canadian J. Genet. and Cytol., 5(1):18-32.

Malakar, R.,1978. Cytogenetical studies of some leguminous plants. M Sc Dissertation Submitted to Central Department of Botany, Tribhuvan University, Nepal.

Manandhar, L. and S.R. Sakya, 2003a. Biological significance of Desmodium Desv. in Nepal Himalayas. In Maskey, S.L., J. L. Shrestha and R. B. Pradhan (eds) Proceedings of International Conference on Woman, Science \& Technology for Poverty Alleviation, Women in Science and Technology (WIST) Nepal, pp 168-171.

Manandhar, L. and S.R. Sakya, 2003b. Karyomorphological observations in Desmodium Desv. and its related taxa of Nepal. Cytologia, 68:121-126.

Manandhar, L. and S.R. Sakya, 2003c. Karyomorphological observations in Desmodium Desv. and its Related Taxa of Nepal. Abstract. Biological Asbstracts, 110(23):344072.

Manandhar, L. and S.R. Sakya, 2004. Cytotaxonimic studies in two species of Astragalus. J. Cytol. Genet., 5:13-20.

Manandhar, L., 2005. Cytogenetical studies in the genus Desmodium Desv. and its allies of Nepal Himalayas, Ph D thesis, Tribhuvan University, Nepal.

Manandhar, L. and S.R. Sakya, 2009. Cytotaxonomy of Smithia ciliata Royle (Fabaceae). Botanica Orientalis, 6:111-113.

Manandhar, L. and B.M. Singh Suwal, 2010. Contribution to the chromosome atlas of the Nepalese flora I. Bulletin of Pure and Applied Science, 29B(2):37-51.

Mangotra, R. and A.K. Koul,1991a. Base number in Genus Crotalaria evidences from meiosis. The Nucleus, 34:158-161.

Mangotra, R. and A.K. Koul, 1991b. Polyploidy in Genus Crotalaria Cytologia, 56:293-296.

Mitra, K. and N. Datta, 1967. IOPB Chromosome number reports XIII. Taxon, 16:445-461.

Muntzing, A.,1941. Differential response to $x$ ray treatment of diploid and tetraploid barley. $\mathrm{K}$. Fysiong. Sallisk. Forh., 11:1-10. 
Nair, C.K.N. and N. Mohanan,1998. Medicinal plants of India with special reference to Ayurveda. Nag Publishers, Delhi, India.

Ohashi, H.,1975. Flora of eastern Himalaya Third report. Univ Mus. Univ Tokyo, Bull., 54-72. Oliviera, A.I., P.C. De and M.L.R. De Aguiar-Perecin,1989. Estudos citogeneticos em 5 especies do geonero Crotalaria (Leguminosae). lencia e cultura (Sao Paulo), 41:678.

Pavlova, D.,1995. Mediteranian chromosome number reports 5(474-478). Flora Mediterranea, 5:317-320.

Peng, C-I and S-M. Chaw,1986. Alysicarpus rugosus (Willd.) DC. A newly naturalized legume species in Taiwan. Bot. Bull. Acad. Sin. (Taipei), 27:247-253.

Press, J.R., K.K. Shrestha and D.A. Sutton, 2000. Annotated checklist of the flowering plants of Nepal. The Natural History Museum, London, UK.

Raina, S.N. and R.C. Verma,1979. Cytogenetics of Crotalaria I. Mitotic complements in twenty species of Crotalaria L. Cytologia, 44:365-375.

Rajbhandari, K.R., 2002-2003. A list of new records of flowering plants of Nepal excluding Graminae and Orchidaceae. NAHSON Bulletin, 12-13:22-29.

Ranjit, J.D.,1978. Cytological studies on some species of Desmodium DC. M Sc Dissertation Submitted to Central Department of Botany, Tribhuvan University, Nepal.

Rao, H.K.S.,1954. Chromosome numbers in some species of the genus Alysicarpus Neck. Current Sci., 23(11):361-362.

Sarkar, A.K., N. Datta, U. Chatterjee and D. Hajra,1982. IOPB Chromosome number reports LXXVI Taxon, 31(3):574-598.

Sanjappa, M. and R.P. Bhatt,1976. IOPB chromosome number reports LIII Taxon, 25:483-500.

Sanjappa, M. and R.P. Bhatt,1977. IOPB chromosome number reports LVI. Taxon, 26(2/3):257274.

Sanjappa, M. and R.P. Bhatt,1978. Cytology of the genus Alysicarpus Neck. ex Desv. (Fabaceae). Cytologia, 43:35-44.

Sanjappa, M. and R.P. Bhatt,1985. Karyomorphological observations in some species of Desmodium Desv. (Fabaceae-Papilionoideae). Cytologia, 50:487-497.

Sareen, T.K. and P.D. Singh,1976. Cytological studies in some north Indian Leguminosae. Proc. Ind. Sci. Cong. Assoc., 63:122-123.

Shrestha, T.B. and R.M. Joshi,1996. Rare, endemic and endangered plants of Nepal. WWF, Nepal Program, Kathmandu.

Sinha, R.P. and K.A. Chandra,1991. Karyotypic analysis in Alysicarpus species. Proceedings of the Indian Congress association, 60:320-321.

Spellenberg, R. and S. Rodrigues,1992. Numeros chromosomicos en algunase species de Astragalus (Fabaceae) y una enmienda a la descripcion de A. zacatecanus (Rydb.) Barneby. 
Acta Botanica Mexicana, 18:17-20.

Tanaka, T.,1976. Tanaka's cyclopedia of edible plants of the world. Keigaku Publishing Co. Tokyo, Japan.

Tuladhar, K.D.,1978. Cytological investigation on some wild legumes. MSc. Dissertation Submitted to Central Department of Botany, Tribhuvan University, Nepal.

Verma, R.C. and S.N. Raina,1983. Cytogenetics of Crotalaria:VIII. Male meiosis in 26 species. Cytologia, 48:719-733.

Yeh, M.S., H. Yussa and F. Maekawa,1986. Chromosome numbers in Leguminosae. Sci. Rep. Res. Inst. Evol. Biol., 3:57-71. 


\section{Legends for Figures:}

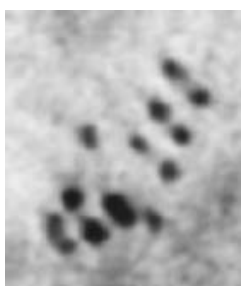

1. Alysicarpus rugosus (Metaphase I with unequal bivalents)

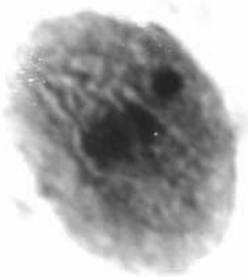

4. Astragalus chlorostachys (Sticky Metaphase I)

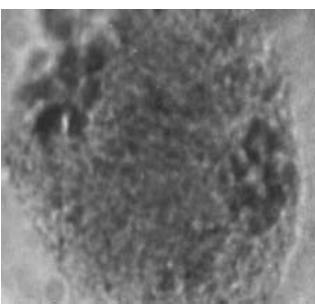

7. Crotalaria pallida (Sticky Metaphase II)

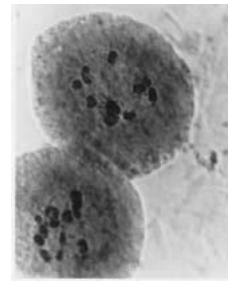

10. Desmodium concinnum var. concinnum (Metaphase I with cytomixis)

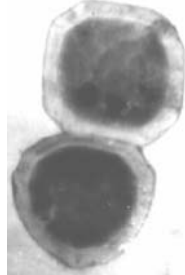

2. Alysicarpus rugosus (Tri and tetracolpate pollens)

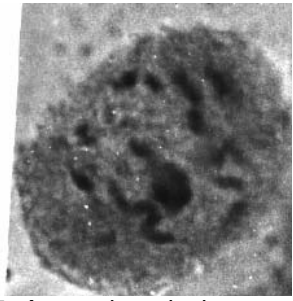

5. Astragalus stipulatus var phulchokiensis (Diakinesis)

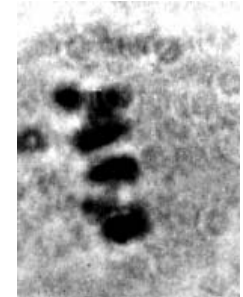

8. Crotalaria sessiliflora (Metaphase I with bivalents and tetravalents)

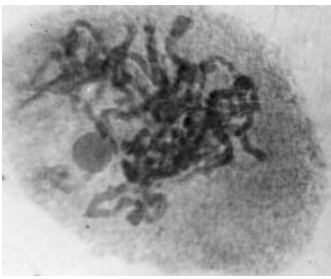

11. Desmodium elegans ssp. elegans var. elegans (Diakinesis)

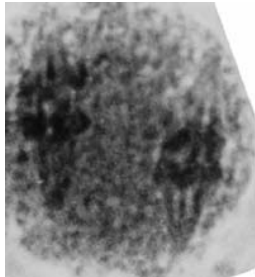

3. Alysicarpus vaginalis (Anaphase II with prcociouc movement of some chromosomes)

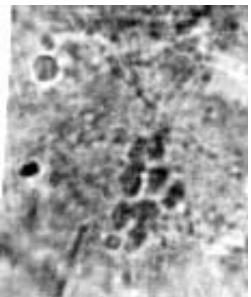

6. Crotalaria cytisoides (Metaphase I with bivalents and tetravalents)

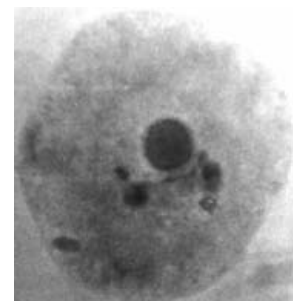

9. Desmodium concinnum var. concinnum (Diakinesis)

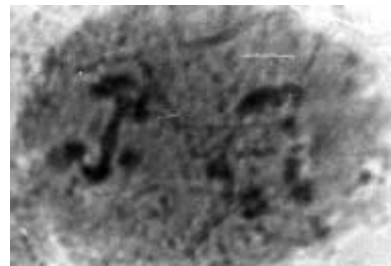

12. Desmodium elegans ssp. elegans var. elegans (Anaphase II with bridge formation) 


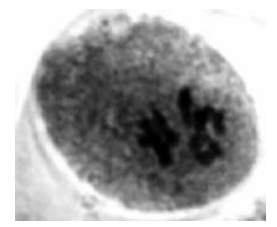

13. Desmodium laxiflorum (Metaphase II with sticky chromosomes)

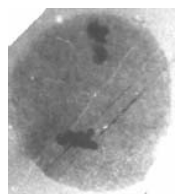

16. Desmodium podocarpum ssp. podocarpum (Sticky Metaphase II)

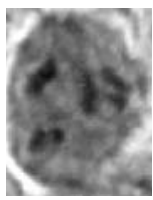

19. Parochetus communis (Anaphase II)

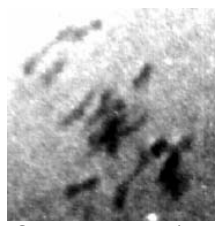

22. Smithia ciliata (Bi and multivalents)

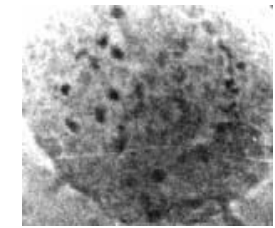

14. Desmodium multiflorum (Metaphase I-tetraploid)

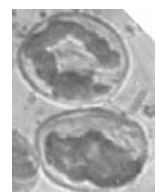

17. Desmodium triflorum (Sticky Metaphase I cells with chromosomes in chain)

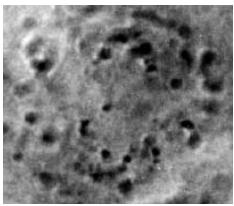

20. Piptanthus nepalensis (Metaphase I-tetraploid cell)

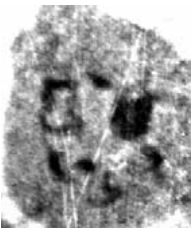

15. Desmodium podocarpum ssp. oxyphyllum var. oxyphyllum (Diakinesis)

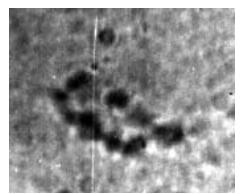

18. Parochetus communis (8 Bivalents in a chain)

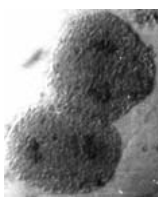

21. Piptanthus nepalensis (Anaphase I with cytomixis)

\section{AUTHOR'S ADDRESS}

\section{Laxmi Manandhar and Shyam Ratna Sakya}

Central Department of Botany, Tribhuvan University

Kirtipur, Kathmandu, Nepal 